Available online on 15.07.2020 at http://ujpr.org
Universal Journal of Pharmaceutical Research
An International Peer Reviewed Journal
Open access to Pharmaceutical research

\title{
AN OVERVIEW ON PHARMACOPOEIAS IN THE WORLD AND MONOGRAPH ELABORATION TECHNIQUES Evren ALGIN YAPAR* ${ }^{*}$, Mehmet Emre ÖZDEMIRHAN \\ Department of Analysis and Control Laboratories, Turkish Medicines and Medical Devices Agency, 06430 Sihhiye, Ankara, Turkey.
}

\section{ABSTRACT}

Pharmacopoeias are official sources that contain national and international rules that must be complied with legally and scientifically regarding substances, materials, drugs, devices and methods used in pharmaceutical field and pharmaceutical production. The monographs are consisted of general titles such as definition, production, characters, identification, tests, assay, storage, labelling and impurities. The World Health Organization states that sixtyeight different pharmacopoeia continue to be used effectively in fifty six countries around the world. In this review information about national and international wold pharmacopoeias, structure and general content of pharmacopoeias, and monograph elaboration techniques are given.

Keywords: General monograph, International pharmacopoeia, monograph elaboration, national monograph, national pharmacopoeia, Pharmacopoeia.

Article Info: Received 26 April 2020; Revised 25 May; Accepted 3 July, Available online 15 July 2020

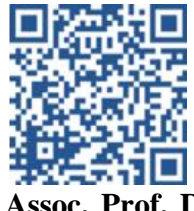

Cite this article-

ALGIN YAPAR E, ÖZDEMIRHAN ME. An overview on Pharmacopoeias in the world and monograph

elaboration techniques. Universal Journal of Pharmaceutical Research 2020; 5(3):57-64.

DOI: https://doi.org/10.22270/ujpr.v5i3.418

Address for Correspondence

Assoc. Prof. Dr. Evren ALGIN YAPAR, Department of Analysis and Control Laboratories, Turkish Medicines and Medical Devices Agency, 06100 Sihhiye, Ankara, Turkey. Tel: +903125655370, E-mail: evrenalgin@yahoo.com

\section{INTRODUCTION}

A pharmacopoeia (pharmacopeia or pharmacopoeia) is a scientific legal binding reference book, prepared by a national or regional authority, of standards and quality specifications for medicines used in that country or region ${ }^{1}$. Pharmacopoeia is official books containing national and international rules and methods that must be followed legally and scientifically, including qualitative and quantitative analysis methods of active substances and excipients used in pharmaceutical production. Monographs refer to the pharmacopoeia section that define the definition, content, morphological (appearance), physicochemical (such as solubility, melting and boiling point) and biological (biological activity and the definition) properties, recognition-diagnostic analysis, quantification, packaging and storage conditions of chemical/biological/biotechnological active and auxiliary substances, herbal/animal drugs and preparations finished products or medicinal products. Pharmacopoeia maintains public health and quality of drugs by combining the procedures recommended for analysis and specifications for the determination of pharmaceuticals, excipients and dosage forms, usually consisting of general sections (tests, methods and general requirements) and special monographs. Pharmaceutical analysis represents a platform through which state-of-the-art research can affect the quality, safety and efficacy of medicines directly by pharmacopoeial application of scientific results into everyday practice ${ }^{2,3}$. The World Health Organization (WHO) states that sixty-eight different pharmacopoeia continue to be used effectively in fifty-six countries around the world and in the European Union, Africa Continent (African Herbal Pharmacopoeia -AfrHP and African Pharmacopoeia), and the WHO structure. Fifty-six countries reported to the WHO have a national pharmacopoeia. Pharmacopoeia of the Eurasian Economic Union (EAEU), European Pharmacopoeia, African Pharmacopoeia, African Herbal Pharmacopoeia are indicated as pharmacopoeia used regional and sub regional. As an international pharmacopoeia, there is The International Pharmacopoeia within the $\mathrm{WHO}^{4}$. A national pharmacopoeia are developed and published by the national pharmacopoeia authority of their country. Information on the name, publisher country and language of the pharmacopoeia of which information are included in the WHO-index and available from various sources, are briefly presented in the Table $1^{4-9}$. 
Table 1: Extensity, name, language and publisher country some of world pharmacopoeias.

\begin{tabular}{|c|c|}
\hline Extensity & Country- Name of Pharmacopoiea - Language \\
\hline \multirow{49}{*}{ National } & Argentina - Farmacopea Argentina - Spanish \\
\hline & Austria - Austrian Pharmacopoeia - Russian \\
\hline & Belarus - State Pharmacopoeia of the Republic of Belarus - Russian \\
\hline & Brazil - Brazilian Pharmacopoeia - Portuguese/English/Spanish \\
\hline & Brazil - Brazilian Homeopathic Pharmacopoeia - Portuguese/English/Spanish \\
\hline & Brazil - National Formulary- Portuguese/English/Spanish \\
\hline & Chile - Farmacopoea Chilena - Spanish \\
\hline & China - Pharmacopoeia of the People's Republic of China - Chinese/English \\
\hline & Croatia - Croatian Pharmacopoeia (HRF) - Croatian \\
\hline & Czechia - Pharmacopoea Bohemica - Czech \\
\hline & Denmark - Pharmacopoea Nordica - Danish \\
\hline & Egypt - Egyptian Pharmacopoeia - Arabic/English \\
\hline & Estonia - Pharmaca Estica - Estonian \\
\hline & France - French Pharmacopoeia - French/English \\
\hline & Germany - German Pharmacopoeia (DAB) - German \\
\hline & Germany - German Homeopathic Pharmacopoeia (HAB) - German \\
\hline & Greece - Greek Pharmacopoeia - Greek \\
\hline & Hungary - Pharmacopoea Hungarica - Hungarian \\
\hline & India - Indian Pharmacopoeia - English \\
\hline & Indonesia - Farmakope Indonesia - Indonesian \\
\hline & Iran - Iranian Pharmacopoeia - Iranian \\
\hline & Italy - Official Pharmacopoeia of the Italian Republic - Italian \\
\hline & Japan - The Japanese Pharmacopoeia (JP) - Japanese/English \\
\hline & Kazakhstan - The State Pharmacopoeia of the Republic of Kazakhstan (SPRK) - Kazakh/Russian \\
\hline & Korea - The Korean Pharmacopoeia - Korean \\
\hline & Lithuania - Lithuanian Pharmacopoeia - Lithuanian \\
\hline & Mexico - Pharmacopoeia of the United Mexican States -Spanish \\
\hline & Mexico - Mexican Herbal Pharmacopoeia- Spanish \\
\hline & Mexico - Mexican Homeopathic Pharmacopoeia - Spanish \\
\hline & Mexico - Pharmacopoeia of the United Mexican States - Spanish \\
\hline & Pakistan - Pakistan Pharmacopoeia - English \\
\hline & Philippines - Philippine Pharmacopeia - English \\
\hline & Poland - Farmakopea Polska - Polish \\
\hline & Portugal - Farmacopeia Portuguesa - Portuguese \\
\hline & Romanian - Pharmacopea Română - Romania \\
\hline & Russian Federation - State Pharmacopoeia of the Russian Federation - Russian \\
\hline & Serbia - Serbian Pharmacopoeia - Serbian \\
\hline & Slovakia - Codex Pharmaceutical Slovacus - Slovak \\
\hline & Slovenia-Formularium Slovenicum - Slovene \\
\hline & Spain - Royal Spanish Pharmacopoeia - Spanish \\
\hline & Switzerland - Pharmacopoea Helvetica - French/German/Italian \\
\hline & Thailand - Thai Pharmacopoeia - English \\
\hline & Thailand - Thai Herbal Pharmacopoeia - English \\
\hline & Turkey - Turkish Pharmacopoiea (TP) - Turkish \\
\hline & Ukraine - The State Pharmacopoeia of Ukraine - Ukrainian \\
\hline & United Kingdom of Great Britain and Northern Ireland - British Pharmacopoeia - English \\
\hline & United States of America - The United States Pharmacopeia and National Formulary (USP-NF)- \\
\hline & English/Spanish \\
\hline & Vietnam - Pharmacopoeia Vietnamica - Vietnamese/English \\
\hline \multirow{4}{*}{$\begin{array}{l}\text { Regional \& } \\
\text { Subregional }\end{array}$} & Eurasia - Pharmacopoeia of the Eurasian Economic Union - Russian (official) \\
\hline & European Pharmacopiea Members - European Pharmacopoeia - English/French \\
\hline & Africa - African Pharmacopoeia - English \\
\hline & Africa - African Herbal Pharmacopoeia (AfrHP) - English \\
\hline International & WHO Geneva, Switzerland - The International Pharmacopoeia - English \\
\hline
\end{tabular}

There are written sources containing substances and preparations in the pharmaceutical field since ancient civilizations in various geographies around the world. The recently published pharmacopoeias compatible with today's pharmacopoeia understanding are respectively; the Russian Pharmacopoeia has been revealed in 1778, the Polish Pharmacopoeia in 1817, the United States Pharmacopeia in 1820, British Pharmacopoeia in 1864, Hungarian Pharmacopoeia in 1871, German Pharmacopoeia in 1872, the Japanese Pharmacopoeia in 1886, Argentina Pharmacopoeia in
1893, the International Pharmacopoeia (WHO) in 1950, Chinese Pharmacopoeia in 1953, the Korean Pharmacopoeia in 1958, Indian Pharmacopoeia in 1960 and the European Pharmacopoeia in 1969. Many pharmacopieas have been developed, revised and enlarged until today ${ }^{10-17}$. As indicated in Table 1 , most of them are available and national, four of them are regional/subrerional and one of them is international. The pharmacopoeias about which information is available are briefly indicated below. 


\section{NATIONAL PHARMACOPOEIAS}

The United States Pharmacopoiea- National Formulary - USP-NF

The first national pharmacopoeia in America was published in 1820 with the idea of creating a national pharmacopoeia for authorized drugs and preparations ${ }^{18}$. USP-NF is published by the United States Pharmacopeia ${ }^{19}$. USP-NF contains official substance (ingredient) and product monographs for official articles recognized in USP-NP. USP-NF also includes the monographs for compounded preparations. With some exceptions, such as the articles contained in the Global Health monographs, all articles that have monographs in the USP-NF are legally marketed or included in the articles marketed in the US. A USP-NF monograph for an official substance, product, or preparation may consist of various components, including the requirements; and a specification. General chapters (General tests and assays, General information, Dietary supplements) supply regularly cited procedures, sometimes with acceptance criteria, in order to compile into one location repetitive information that is applicable to many monographs. USP-NF also includes monographs, NF Admissions/ Annotations, Excipients, NF monographs, Reagents Indicators and Solutions, Chromatographic columns, Reference tablets monographs, Dietary supplements monographs ${ }^{20,21}$.

\section{The British Pharmacopoeia - BP}

The British Pharmacopoeia has been providing official standards for medicines since $1864^{22}$. The Pharmacopoeial standards are designed to complement and assist the licensing and inspection processes and are part of the overall system for safeguarding purchasers and users of medicinal products in the UK. The British Pharmacopoeia is published by the British Pharmacopoeia Commission, Medicines and Healthcare products Regulatory Agency-MHRA. The British Pharmacopoeia contains publicly available, legally enforceable standards that provide an authoritative statement of the quality that a product, material or article is expected to meet at any time during its period of use. It includes General Notices, Monographs (Medicinal and Pharmaceutical Substances, Formulated Preparations: General Monographs, Formulated Preparations: Specific Monographs, Herbal Drugs, Herbal Drug Preparations and Herbal Medicinal Products, Materials for use in the Manufacture of Homoeopathic Preparations, Bloodrelated Products, Immunological Products, Radiopharmaceutical Preparations, Surgical Materials), Infrared Reference Spectra chapter and Veterinary Volume ${ }^{23}$.

\section{The Japanese Pharmacopoeia - JP}

Japanese Pharmacopoeia was first published in $1886^{24}$.The Japanese Pharmacopoeia is promulgated by the Ministry of Health, Labour and Welfare-MHLW that is an official document that defines the specifications, criteria and standard test methods necessary to properly assure the quality of medicines in Japan.The Japanese Pharmacopoeia includes General Notices, General Rules for Crude Drugs and Preparations, General Tests, Processes and Apparatus
(Chemical Methods, Physical Methods, Powder Property Determinations, Biological Tests/Biochemical Tests/Microbial Tests, Tests for Crude Drugs, Tests for Preparations, Tests for Containers and Packing Materials, Reference Standards; Standard Solutions; Reagents, Test Solutions; Measuring Instruments, Appliances, etc.), Official Monographs, Crude Drugs and Related Drugs, Infrared Reference Spectra, Ultraviolet-visible Reference Spectra and General Information (Physics and Chemistry, Solid-state Properties, Biotechnological/Biological Products, Microorganisms, Crude Drugs, Drug Formulation, Containers and Package, Water, Reference Standards, International Harmonization) monographs ${ }^{25}$.

\section{The Turkish Pharmacopoiea- TP}

The first known Turkish national standard about materials, substances and preparations in the world was declared in 1502 during the time of Ottoman Empire of Sultan Beyazit Han. The process that started with the publication of the first pharmacopoeia in Istanbul in 1818 has developed and diversified until today. The original text of the "Kanunname-i İhtisab-1 Bursa" in Istanbul Topkapı Museum Revan Library was prepared by Sultan II. Bayezid Han in 1502 as edict. In this document, the quantity, weight, size and packaging characteristics and standards of various materials such as herbal products, textiles, food products and salt have been determined. The standard has been reprinted by the Turkish Standards Institution with the preservation of its original text and dimensions ${ }^{10-13}$. The first official pharmacopoeia of the Republic of Turkey which contains 659 monograph was published in 1930 under the name of "Turkish Codex"14. The Republic of Turkey is one of the 39 member states of the European Pharmacopoeia. European Pharmacopoeia used officially in Turkey but also the Turkish Pharmacopoeia continues its existence. The Turkish Pharmacopoeia is prepared by the Turkish Medicines and Medical Devices Agency-TMMDA and the official broadcast is "Turkish Pharmacopoeia Journal". National monographs that are newly added, updated, corrected in the Turkish Pharmacopoeia are announced before this publication. Turkish Pharmacopoeia includes European Pharmacopoeia monographs as well as national monographs. It also has a section containing magistral preparation monographs in a separate volume. After elaborating monographs such as chemical, herbal, biological or biotechnological products and finished products, they are published in the Turkish Pharmacopoeia Journal and then in the Turkish Pharmacopoeia and become official. Since the $7^{\text {th }}$ version of the Turkish Pharmacopoeia published in 2017, the pharmacopoeia is being expanded with the increasing number of national monographs every year. In the 2019 version, the number of national monographs has reached thirty two and most of them are monographs of medicinal and aromatic herbal ingredients ${ }^{26}$.

\section{Pharmacopoeia of the People's Republic of China -} ChP

The ministry of health published the Rebublic of China's first pharmacopoeia as Chinese Pharmacopoeia in 1953. Under the umbrella of the China Food and 
Drug Administration- CFDA, the Chinese Pharmacopoeia Commission-ChPC and its stakeholders (drug control institutions, research institutions, universities and drug manufacturers) prepare the Chinese Pharmacopoeia in line with the basic principles, goals and requirements of the era. The Chinese Pharmacopoeia comprise monographs of vegetable, oil fat and extracts, medicinal materials and the prepared slices of Chinese crude drugs, single-item preparations, chemical drugs, antibiotics, biochemical and radioactive drugs, pharmaceutical excipients andbiologicals. General Chapters includes general requirements of preparations, testing methods, standard substances, reagents and guidelines ${ }^{27,28}$.

\section{Farmacopea Argentina}

Farmacopea Argentina is published by The National Administration of Medicines Food and Medical Technology-ANMAT. The $8^{\text {th }}$ Edition (Vol 1, 2, 3, 4) was released in 2011 and its language is Spanish. Farmacopea Argentina provides specification via monographs for APIs and excipients, for finished dosage forms, for biological, for herbal products, for medical products, for blood products, for radiopharmaceutical products, for vaccines and including general monographs and supplementary texts $^{4,29}$.

\section{Brazilian Pharmacopoeia}

Brazilian Pharmacopoeia is published by Pharmacopoeia Coordination Brazilian Health Surveillance Agency-ANVISA in three languages, Portuguese, English and Spanish. Apart from Brazilian Pharmacopoeia, Brazilian Homeopathic Pharmacopoeia (Portuguese/English/Spanish) [30], National Formulary (Portuguese/English/Spanish), Herbal Medicines National Formulary (Portuguese/ Spanish), Homeopathic Medicines National Formulary (Portuguese/English/Spanish), Herbal Medicines Memento (Portuguese) are also used in Brasil. Brazilian Pharmacopoeia provides specification via monographs for APIs and excipients, for dosage forms, for biological, for herbal products and including monographs for medical devices ${ }^{4,31}$.

\section{German Pharmacopoeia - DAB}

German Pharmacopoeiais published by Federal Institute for Drugs and Medical Devices-BfArM in German $^{4,32}$. Also German Homeopathic Pharmacopoeia -HAB is used in Germany ${ }^{33}$. German Pharmacopoeia provides spesifications and monographs for APIs, dosage forms, herbal products, biological and traditional medicines, traditional and complemantary medicines, excipients, vaccines, general monographs on different product groups, analytical methods, analytical procedures, microbiological requirements, statistical methods, packaging materials and containers. Additionally informations for extemporaneous preparations, magistral formulas, APIs and excipients used for these preparations, test procedures used for them in pharmacies and formulas used in hospital pharmacies. German Homeopathic Pharmacopoeia includes spesifications and monographs for homoeopathic raw materials and homoepathic manufacturing methods, etc ${ }^{4,32,33}$.

\section{Indian Pharmacopoeia}

Indian Pharmacopoeia Commission-IPC (on behalf of the Ministry of Health and Family Welfare) publish Indian Pharmacopoeia in English. The pharmacopoeia comprises analysis and specification procedures (for the determination of quality of pharmaceutical substances, excipients and dosage forms). The monographs comprises the articles about definition, description, identification, packing, storage, specifications, impurities, assay and specific tests, analytical procedures for tests, acceptance criteria, other requirements et cetera. It includes General Chapters and Reference Data, General Notices, Dosage Forms (General Monographs), Drug Substances, Dosage Forms and Pharmaceutical Aids, Vaccines and Immunosera for Human Use, Herbs and Herbal Products, Blood and Blood-related Products, Biotechnology Products; Veterinary Products ${ }^{34,35}$. Also Indian Homeopathic Pharmacopoeia is used in India ${ }^{36}$. Iranian Pharmacopoeia

Persian pharmacy history dates back to ancient times. Qarabadins were a kind of pharmaceutical books which was the first generation of pharmacopeias in the history, and these books were a registry of drugs and preparations containing dosage forms, preparation procedures, considerations, dose of administrations, shelf life, etc. The transition to modern pharmacopoeia in Iran started to be written recently, and modern medicine has replaced the Persian medicine, and new pharmacy education and practices have started. The first Iranian pharmacopoeia was published in 2004 by Iranian Ministry of Health. During later years, five other volumes of this pharmacopeia were published. The last $\left(6^{\text {th }}\right)$ volume was published in $2015^{37,38}$.

\section{Pharmacopoeia of the United Mexican States}

Pharmacopoeia of the United Mexican States is published by Permanent Commission of the Pharmacopoeia of the United Mexican States in Spanish. Also Mexican Herbal Pharmacopoeia, Mexican Homeopathic Pharmacopoeia ${ }^{39}$, Medical devices Supplement and Pharmacies Supplement is used in Mexico. Mexican Pharmacopoeia includes monographs for general methods of analysis, monographs of additives, drug monographs, monographs for medicines, monographs of medical gases, monographs of biological products, monographs of dissolution profiles, and a supplement for the monograps for medical devices. Pharmacies Supplement includes informations for controlled drugs, officinal drugs, management and conservation of health products, issues for damaged drugs, informations for pharmacovigilance and tecnovigilance for hospital pharmacy, pharmacies and ware houses. Herbal Pharmacopoeia provides official monograps, monographs for Mexican plants and general methods for analysis. Homeopatic Pharmacopoeia provides spesifications and monographs for homeopathic active ingredients and homeopathic tinctures, also information for homeopathic pharmacies ${ }^{4,40}$.

\section{Thai Pharmacopoeia}

Thai Pharmacopoeia is published by Thai Pharmacopoeia Committee Bureau of Drug and Narcotic Department of Medical Sciences on behalf of 
the Ministry of Public Health in English ${ }^{4}$. It includes Raw material monographs, finished product monographs and infrared reference spectras $^{41}$. Thai Homeopathic Pharmacopoeia is also used in Thailand ${ }^{4}$.Homeopathy therapy is one of the most widely used alternative medicine branches in the world and opted as a potential treatment by many people that process is activated by giving medicines made from substances found in the vegetable, aminal and mineral resources $^{42,43}$.

\section{Czech Pharmacopoeia}

The Czechoslovak Pharmacopoeia $1^{\text {st }}$ Edition (this pharmacopoeia was prepared before World War II in 1937 but was published as late as 1947 due to Nazi occupation) with one supplement published in 1953.The $2^{\text {nd }}$ Edition was published in 1954 with a supplement issued in 1959.The $3^{\text {rd }}$ Edition issued in 1970 in two volumes with one supplement in 1976. The $4^{\text {th }}$ Edition was published in 1987 as the last authentic and team work pharmacopoeia for the Czechoslovak Republic. Czech Pharmacopoeia published by the Ministry of Health of the Czech Republic which establishes the procedures and requirements for the manufacture of active substances and excipients, the manufacture and preparation of medicinal products, testing and storage of active substances, excipients and medicinal products. Czech Pharmacopoeia includes APIs and excipients, pharmaceutical preparations, monographs for herbal products (together with APIs and excipients), finished dosage forms, general monographs and supplementary texts (Reagents and references substance used in national monographs; tables: List of narcotics and psychotropic substances etc.) ${ }^{44-46}$

\section{Regional and Subregional Pharmacopoeias The European Pharmacopoeia - EP}

The $1^{\text {st }}$ Edition of European Pharmacopoeia was published as three bound volumes between 1968 and $1976^{47}$. By replacing the Convention on the Elaboration of the European Pharmacopoeia with the Convention Protocol signed by the Governments of 38 member states (Austria, Belgium, Bosnia and Herzegovina, Bulgaria, Croatia, Cyprus, Czech Republic, Denmark, Estonia, Finland, France, Germany, Greece, Hungary, Iceland, Ireland, Italy, Latvia, Lithuania, Luxembourg, Malta, Montenegro, Netherlands, North Macedonia, Norway, Poland, Portugal, Republic of Moldova, Romania, Serbia, Slovak Republic, Slovenia, Spain, Sweden, Switzerland, Turkey, Ukraine, United Kingdom) and the European Union, the European Pharmacopoeia was prepared under the umbrella of the Council of Europe. The preparation of the EP is the control of the European Pharmacopoeia Commission, appointed in accordance of the above-mentioned Convention. It is consist of delegations designated by the Contracting Parties. Each delegation comprises of a maximum of three members chosen for their proficiency in matters within the functions of the Commission $^{48}$.The European Pharmacopoeia is within the body of European Directorate for the Quality of Medicines \& HealthCare-EDQM and the official broadcast is Pharmeuropa ${ }^{49}$. Monographs that are newly added, updated, corrected or planned to be deleted in the European Pharmacopoeia are announced before this publication. European Pharmacopoeia includes, General chapters (General notices, Methods of analysis, Materials for containers and containers, Reagents, General texts), General monographs, Monographs on dosage forms, Vaccines for human use and veterinary use, Immunosera for human use and veterinary use, Radiopharmaceutical preparations and starting materials for radiopharmaceutical preparations, Sutures for human use and veterinary use, Herbal drugs and herbal drug preparations, Homoeopathic preparations and monographs $\mathrm{s}^{4,50,51}$.

Pharmacopoeia of the Eurasian Economic Union

$1^{\text {st }}$ Edition of Pharmacopoeia of the Eurasian Economic Union is published by Pharmacopoeial Committee of the Eurasian Economic Union on behalf of the Eurasian Economic Commission in 2019. It is planned to publish the official language in Russian every 3 years. Participating countries in the Pharmacopoeia the Eurasian Economic Union: Armenia, Belarus, Kazakhstan, Kyrgyzstan and the Russian Federation ${ }^{4,52}$.

\section{African Pharmacopoeia}

African Pharmacopoeia is published by African Union Scientific Technical Research Commission-STRC in English. African Herbal Pharmacopoeia -AfrHP, another official source used in Africa is published by Association for African Medicinal Plants Standards in English ${ }^{4,53}$.

\section{International Pharmacopoeia}

The International Pharmacopoeia-Ph.Int.

The International Pharmacopoeia was born in 1874 based on the need to standardize terminology, determine the composition and dosage of drugs. Ph. Int. includes the accumulation of recommended procedures for analysis and specifications for the identification of pharmaceutical substances, adjuvants and dosage forms intended to serve as resource materials for reference or adaptation by any WHO Member State intended to build the needs ${ }^{54,55}$. Ph. Int. compared to national and regional pharmacopoeias, it is published by WHO as a recommendation to help achieve a global quality specificity by providing international standards (including less technically claiming alternatives where needed) for pharmaceutical products, adjuvants and dosage forms to be accepted by Member States ${ }^{2}$. It includes General Notices, Appendices to the General Notices, Pharmaceutical Substances monographs, Dosage Forms (General and specific monographs), Radiopharmaceuticals (General monographs, Specific monographs, Methods of analysis (Physical and physicochemical/Chemical/ Biological methods), Supplementary information), Methods of Analysis (Physical and physicochemical methods, Chemical methods, Biological methods, Methods for materials of plant origin and Pharmaceutical technical procedures), Infrared Reference Spectra chapter, Reagents, test solutions and volumetric solutions and Supplementary information $^{54,56}$.

\section{Content of Pharmacopoeias}

Pharmacopoeias consist of general chapters and medicinal and pharmaceutical substances monographs, starting with the preface, introduction and general 
notices. The monographs whose title/monograph number has changed and new, revised, corrected, deleted monograph information is indicated. Methods of analysis chapter describing many analytical methods to be applied in analysis with biological tests and assays, materials for containers and containers chapter describing the materials are used for the manufacture of containers for pharmaceutical use, Reagents chapters containing a description of the solutions prepared for tests and analyzes with specified standards, Monographs on Dosage forms, Vaccines, Immunoseras, Blood-related Products Immunological Products, Radiopharmaceuticals, medical devices Herbal drugs and herbal drug preparations, Homoeopathic preparations and monographs, Infrared/Ultravioletvisible Reference Spectra information of chemicals, Formulated Preparations and finished product monographs can be described as parts of pharmacopoeia $^{20,23,25,50}$. The quality control of pharmaceutical products has a great prospect in terms of the safe access to treatment that patients need. The quality of the pharmaceutical products used must comply with relevant internationally accepted criteria ${ }^{57}$. Quality in pharmaceutical products is a broad concept covering all aspects that affect the efficacy and safety of these products. All of the measures that require the assurance of pharmaceutical quality constitute the quality assurance system ${ }^{58}$. The Quality Assurance system consists of Quality Management (QM), Quality Assurance (QA) and Good Manufacturing Practices (GMP) and Quality Control (QC). Pharmaceutical products are subjected to quality control criteria and analysis within the scope of internationally accepted standards and guidelines specified or guided, including formulation, place and form of use. Pharmacopoeias shed light on many aspects of quality control analyzes in pharmaceutical products ${ }^{59}$. Basically, pharmaceutical scientists should be careful to select the material in accordance with the appropriate standards and specified quality criteria, with very careful handling of the materials use process to obtain a consistent pharmaceutical product ${ }^{60}$.

\section{Monograph Elaboration Tecniques}

Monographs are elaborated or revised according to certain accepted patterns. EDQM and WHO have published detailed documents on monograph elaboration techniques and procedures. The published documents are updated by intermediate and published on the official web pages ${ }^{61}$. Countries involved in monograph studies follow and implement these procedures. EDQM has developed detailed guides for monograph elaboration as well as study techniques and publishes new ones as needed. Brief information about these guides is given below. Style Guide of the European Pharmacopoeia has been produced to help all those involved in the preparation of monographs for the European Pharmacopoeia-Ph.Eur.: the groups of experts, secretaries of these groups, translators, national secretariats. This Guide supplies the means of drafting clear unambiguous texts, with alike requirements presented in the likewise in each monograph. A uniform format is very helpful in understanding and communicating information clearly.
An analyst who has already carried out a test prescribed in the Ph. Eur. will find it easier to set up and carry out a similar test presented in the same way $^{62}$. A guide to the graphic representation and nomenclature of chemical formulae in the European Pharmacopoeia is the guide on nomenclature and graphic representation of chemical formulae has been prepared to reply to a number of questions from the European Pharmacopoeia Commission and users of the $\mathrm{Ph}$. Eur ${ }^{63}$. Technical guide for the elaboration of monographs is a guide for the authors of monographs and also a means of communicating the principles for the elaboration of monographs to the users of the European Pharmacopoeia, especially industry, licensing authorities and official medicines control laboratories ${ }^{64}$. Guide for the elaboration of monographs on vaccines and immunosera for human use is intended to provide guidance to authors, contributors and users of European Pharmacopoeia on the elaboration of monographs for vaccines and other immunological human medicinal products ${ }^{65}$. Technical Guide for the elaboration of monographs on synthetic peptides and recombinant DNA proteins is intended to provide guidance to authors, contributors and users of the European Pharmacopoeia on the elaboration of active substance monographs for synthetic peptides and products of recombinant DNA technology, referred to as rDNA proteins throughout the document ${ }^{66}$. General principles for monographs on finished products containing chemically defined active substances is intended to provide additional information to users on how to read and apply future individual FP monographs. It shall be read in conjunction with the European Pharmacopoeia. General Notices, the relevant dosage form monograph and the general monograph on Pharmaceutical Preparations ${ }^{67}$. Guide for the elaboration of monographs on homoeopathic preparations is about stocks for homoeopathic preparations may be of a mineral, chemical, botanical, zoological or human origin. This Guide develops the specific points which are appropriate to monographs for homoeopathic preparations, and which are not presented in the Technical Guide for the Elaboration of Monographs (referred to as the Technical Guide) and of the Ph. Eur. Style Guide ${ }^{68}$. Technical Guide for the elaboration and use of monographs on human plasmaderived products is intended to provide guidance to authors, contributors and users of European Pharmacopoeia monographs and general chapters on medicinal products derived from human blood and human plasma ${ }^{69}$. Guide for the elaboration of monographs on radiopharmaceutical preparations is used for the elaboration of monographs on radiopharmaceutical preparations supplements the latest versions of both the Style guide of the European Pharmacopoeia and the Technical Guide for the elaboration of monographs. Special topics related only to radiopharmaceutical preparations are noted in this guide $^{70}$. Technical Guide for the elaboration and use of monographs for vaccines and immunological veterinary medicinal products is intended to provide guidance to authors, contributors and users of European Pharmacopoeia monographs on veterinary 
vaccines and other immunological veterinary medicinal products $^{71}$. Technical Guide for the elaboration of monographs on fatty oils and derivatives, a guide which is using to achieve harmonised monographs. Accordingly, in revision of a monograph or in the creation of a new monograph, it should be added to the monograph if it is useful and suitable, taking into account the analytical parameters specified in these guidelines $^{72}$. Technical Guide for the elaboration of monographs on herbal drugs and herbal drug preparations is a guide for developing specific points unavailable in the above-mentioned general Guidelines regarding to herbal drug and herbal drug preparations monographs. It is recalled that all tests and assay methods described in a monograph must be validated according to the procedures stated in the Technical guide $^{73}$. Procedure for the elaboration, revision and omission of monographs and other texts for The International Pharmacopoeia was created for $\mathrm{Ph}$. Int. monographs. Monographs are developed in accordance with the principles in the Good Pharmacopoeia Practices (GPhP), in a clear process and aim to harmonization and convergence of compendial quality standards to ultimately increase access to affordable, quality-assured medicines ${ }^{74}$.

\section{CONCLUSION}

In parallel with the advances in the scientific and technological fields and the developments in the pharmaceutical and analytical fields, the development and revisions of the pharmacopoeias will continue.

\section{AUTHOR'S CONTRIBUTION}

All authors have worked equally for this work.

\section{ACKNOWLEDGEMENTS}

The authors extend their thanks and appreciation to the Turkish Medicines and Medical Devices Agency to provide necessary facilities for this work.

\section{CONFLICT OF INTEREST}

No conflict of interest associated with this work.

\section{REFERENCES}

1. World Health Organization: International Meeting of World Pharmacopoieas. Working document, March 2013; 1-20.

2. The International Pharmacopoeia, WHO Drug Information 2013; 27(2):119-128.

3. Kameyama Y, Matsuhama M, Mizumaru C, Saito R, Ando T, Miyazaki S. Comparative study of pharmacopoeias in japan, europe, and the united states: Toward the further convergence of international pharmacopoeial standards. Chem Pharm Bull 2019; 67(12):1301-1313.

https://doi.org/10.1248/cpb.c19-00621

4. World Health Organization: Index of World Pharmacopoieas and Pharmacopoeial Authorities. Working document, February 2020, p1-52. Available: http://www10.who.int/medicines/areas/quality_safety/qualit y assurance/resources/INDEX-OF-

PHARMACOPOEIAS_2020.pdf

5. Otter M. The first official Estonian Pharmacopoeia. Acta Medico-Historica Rigensia 2000; 247-250.

https://doi.org/10.25143/amhr.2000.V.21

6. Medicines and Medical Devices Agency of Serbia: Pharmacopoeia. Available: https://www.alims.gov.rs/eng/ regulations/ pharmacopoeial
7. World Health Organization: International Meeting of World Pharmacopoieas. Answers from pharmacopoeias. International Meeting of World Pharmacopoeias, March 2012.

8. Cvelbar M, Šmid-Korbar J, Budihna M. Pharmaceutical Legislation: European Pharmacopoeia and Formularium Slovenicum with supplements. Zdrav Vestn 2003; 72(1): 25-26.

https://vestnik.szd.si/index.php/ZdravVest/article/view/1780

9. Turkish Medicines and Medical Devices Agency: Pharmacopoiea.

https://www.titck.gov.tr/faaliyetalanlari/laboratuvar/farmak ope

10. Ágoston G, Masters B. Encyclopedia of the Ottoman Empire 2009; 264-391. Available:

11. The Law of the Municipality of Bursa, Turkish Standards Institution, $2013 . \quad$ Available: https://statik.tse.org.tr/upload/tr/dosya/icerikyonetimi/7865/ 26092017113800-2.pdf

12. Encyclopedia of Ahilik Vol.-II, Republic of Turkey, Ministry of Customs and Trade, Directorate General of Craftsmen and Artisans, 2017;25-26. https://esnafkoop.ticaret.gov.tr/data/5d403ec913b8762a64e 9050c/50dbf4347dd639bf210e2b2e677612f0.pdf

13. Demirkol TP. The Bursa Specialization Law as a Market Regulatory Mechanism. Med J Humanit 2017; 7(2): 149158. https://doi.org/10.13114/MJH.2017.354

14. Özkan Y. Türk Farmakopesi' nintarihselgelişimi. Türk Farmakope Dergisi 2016; 1(1): 21-33.

15. Urdang G. The Development of Pharmacopoeias. Bull World Hlth Organ 1951; 4(4): 575-603. PMID: 14925813

16. Simon C, Lamia M. Merging Pharmacopoeia: understanding the historical origins of incorporative pharmacopoeial processes among Xhosa healers in Southern Africa. J Ethnopharmacol 1991; 33(3): 237-242. https://doi.org/10.1016/0378-8741(91)90083-P

17. de Oliveira Martins DT, Rodrigues E, Casu L, Benítez G, Leonti M. The historical development of pharmacopoeias and the inclusion of exotic herbal drugs with a focus on Europe and Brazil. J Ethnopharmacol 2019; 240: 111891. https://doi.org/10.1016/j.jep.2019.111891

18. Haller JS. The United States Pharmacopoeia Its Origin and Revision in the $19^{\text {th }}$ Century. Bull NY Acad Med 1982; 58(5): 480. PMID: 7052180

19. The United States Pharmacopoeia, USP. Available: https://www.usp.org

20. The United States Pharmacopoeia 42 - National Formulary 37, Second Supplement, The United States Pharmacopeial Convention, Rockville, 2019.

21. Bagirova VL, Kovaleva EL, Shanazarov KS. Preparing a pharmacopoeial article on pharmaceutical substances. Pharm Chem J 2007; 41:34-36. https://doi.org/10.1007/s11094-007-0008-3

22. The British Pharmacopoeia. Available: https://www.pharmacopoeia.com/the-british-pharmacopoeia

23. The British Pharmacopoeia, Volume I, Medicines and Healthcare Products Regulatory Agency, British Pharmacopoeia Commision, 2019.

24. JP History and Legal Status, Japanese Pharmaceuticals and Medical Devices Agency. https://www.pmda.go.jp/files/000234418.pdf

25. The Japanese Pharmacopoeia $17^{\text {th }}$ Edition, English Version, The Minister of Health, Labour and Welfare, 2016.

26. Turkish Pharmacopoeia 7th Edition, Republic of Turkey Ministry of Health, 2019.

27. Pharmacopoeia of The People's Rebublic of China, Chinese Pharmacopoeia Commision, China Medical Science Press, 2015.

28. Chinese Pharmacopoeia. http://wp.chp.org.cn/en/content.html

29. Farmacopea Argentina. Available: http://www.anmat.gov.ar/fna/septima_edicion.html

30. Brazilian Homeopathic Pharmacopoeia $3^{\text {rd }}$ Edition, Brazilian Health Surveillance Agency 2011; 1-300. 
http://portal.anvisa.gov.br/documents

31. The Brazilian Health Regulatory Agency.: http://portal.anvisa.gov.br/

32. The Federal Institute for Drugs and Medical Devices https://www.bfarm.de/EN/Home/home_node.html

33. German Homoeopathic Pharmacopoeia Vol. I. Stuttgart: medpharm GmbH Scientific Publishers, 2003.

34. Indian Pharmacopoeia, $6^{\text {th }}$ Edition (6.0), Indian Pharmacopoeia Commision, Ministry of Health and Family Welfare Government of India, 2010.

35. Indian Pharmacopoeia Commission. http://www.ipc.gov.in

36. Indian Homoeopathic Pharmacopoeia, Volume 10, Indian Homoeopathy Pharmacopoeia Commision, Ministry of Health and Family Welfare Government of India, 2010

37. Zargaran A, Zarshenas MM. The History of Pharmacopeias in Iran (Persia): From Antiquity to Current Era. Working Group History of Pharmacopeia, International Society for the History of Pharmacy 2017. http://www.histpharm.org/ISHPWG\%20Iran.pdf

38. Iran Ministry of Health and Medical Education. https://behdasht.gov.ir

39. Farmacopea Homeopática de los Estados Unidos Mexicanos, Primera Edición, Farmacopea Homeopática de los Estados Unidos Mexicanos Comisión Permanente de los Estados Unidos Mexicanos, Altres, Costa-Amic, México, 1998.

40. Farmacopea de los Estados Unidos Mexicanos, Duodécima Edición, Farmacopea Homeopática de los Estados Unidos Mexicanos Comisión Permanente de los Estados Unidos Mexicanos, Altres, Costa-Amic, México, 2018.

41. Thai Pharmacopoeia - Bureau of Drug and Narcotic. http://dmsc2.dmsc.moph.go.th/webroot/drug/eng/TP_eng/tp _thp.stm

42. Tinprapa N. Legal Measures on Homeopathy in Thailand. Thammasat Business Law Journal 2015; 5: 1-9. ISSN (Online) $2672-9072$.

43. Josephson L. A homoeopathic handbook of natural remedies, $1^{\text {st }}$ Edition, 2020. ISBN 0-8129-9188-5.

44. Czech Pharmacopoeia, State Institute for Drug Control http://www.sukl.eu/pharmaceutical-industry/informace-ohistorii-a-soucasnosti-ceskeho-lekopisu

45. Subert J. On the content of the national part of the czech pharmacopoeia from the aspect of the formulation of medicinal preparations in pharmacies. Ceska Slov Farm 2008; 57(3): 132-134.

46. Šubert J, Kolár J. On the content of the national part of the czech pharmacopoeia 2017. Ceska Slov Farm 2018; 67(2): 81-84. PMID: 30189737

47. I. Preface of the $10^{\text {th }}$ Edition of the $\mathrm{Ph}$. Eur, European Pharmacopoeia 10.0, European Directorate for the Quality of Medicines and Health Care, Strasbourg, 2020.

48. II. Introduction, European Pharmacopoeia 10.1, European Directorate for the Quality of Medicines and Health Care, Strasbourg, 2020.

49. Scheepers H. Pharmacy preparations: European quality standards and regulation. Universitaire Pers Maastricht 2017;9-14. ISBN 9789461596819.

50. European Pharmacopoeia 10.1, European Directorate for the Quality of Medicines and Health Care, Strasbourg, 2020.

51. European Pharmacopoeia. https://pheur.edqm.eu/app/10-1/search

52. Eurasian Economic Commission. http://www.eurasiancommission.org/ru/act

53. Association for African Medicinal Plants Standards. https://www.aamps.org

54. Preface: The International Pharmacopoeia, $9^{\text {th }}$ Edition, WHO Expert Committee on Specifications for Pharmaceutical Preparations, 2019.

55. The International Pharmacopoeia, 9th Edition, WHO Expert Committee on Specifications for Pharmaceutical Preparations, 2019.
56. WHO Expert committee on specifications for pharmaceutical preparations. Technical report series no: 996. World Health Organization 2016:7-15.

57. Olefir YV, Sakanyan EI, Luttseva AI, et al. Validation of Methods and Procedures in Pharmacopoeial Monographs in the Framework of a Drug Standardization Program. Pharm Chem J 2019; 52:873-877. https://doi.org/10.1007/s11094-019-1919-5

58. Siddiqui MR, AlOthman ZA, Rahman N. Analytical techniques in pharmaceutical analysis: A review. Arabian J Chemistry, 2017; 10:1409-1421. https://doi.org/10.1016/j.arabjc.2013.04.016asd

59. Algın Yapar E, Özdemirhan ME, Kızılay H, Gürsöz H. Analysis of biological/biotechnological medicines in pharmacopoeias. Bio Turkey - International Biotechnology Congress, 2020, PN-016.

60. Van Heugten AJ, Versluijs-Helder M, Vromans $\mathrm{H}$. Elucidation of the variability in consistency of pharmacopoeia quality petrolatum. Drug Dev Ind Pharm 2017; 43(4): 595-599. https://doi.org/10.1080/03639045.2016.1274902

61. Council of Europe: Technical Guides. https://www.edqm.eu/en/technical-guides

62. Style guide of the european pharmacopoeia, European Directorate for the Quality of Medicines and Health Care, Strasbourg, 2017; 1-91.

63. A guide to the graphic representation and nomenclature of chemical formulae in the European Pharmacopoeia, 2nd Edition, European Directorate for the Quality of Medicines and Health Care, Strasbourg, 2011;1-40.

64. Technical guide for the elaboration of monographs, 7th Edition, European Directorate for the Quality of Medicines and Health Care, Strasbourg, 2015;1-74

65. Guide for the elaboration and use of monographs on vaccines and immunosera for human use, European Directorate for the Quality of Medicines and Health Care, Strasbourg, 2019; 1-24.

66. Technical guide for the elaboration of monographs on synthetic peptides and recombinant DNA proteins, 2nd Revision, European Directorate for the Quality of Medicines and Health Care, Strasbourg, 2018;1-18.

67. General principles for monographs on finished products (FPs) containing chemically defined active substances, European Directorate for the quality of medicines and health care, Strasbourg, 2017;1-3.

68. Guide for the elaboration of monographs on homoeopathic preparations, European Directorate for the Quality of Medicines and Health Care, Strasbourg 2013;1-32.

69. Technical guide for the elaboration and use of monographs and general chapters on human plasma-derived products, European Directorate for the Quality of Medicines and Health Care, Strasbourg 2015;1-20.

70. Guide for the elaboration of monographs on radiopharmaceutical preparations, European Directorate for the Quality of Medicines and Health Care, Strasbourg, 2018; $1-40$.

71. Technical guide for the elaboration and use of monographs for vaccines and immunological veterinary medicinal products, $2^{\text {nd }}$ Revision, European Directorate for the Quality of Medicines and Health Care, Strasbourg, 2020;1-26.

72. Technical guide for the elaboration of monographs on fatty oils and derivatives and on some polymers and solvents, European Directorate for the Quality of Medicines and Health Care, Strasbourg, 2007;1-23

73. Guide for the elaboration of monographs on herbal drugs and herbal drug preparations, European Directorate for the Quality of Medicines and Health Care, Strasbourg, 2007;122.

74. Procedure for the elaboration, revision and omission of monographs and other texts for the international pharmacopoeia, WHO Drug Information , World Health Organization, Geneva, 2019;33(2):174-178. ISSN 10109609. 